The main goal of this study was to draw the attention of physicians to commonly undisclosed risk of breast cancer $(\mathrm{BrCa})$ in women suffering from neurofibromatosis type 1 (NF-1), which is 5 -fold higher than in the general population. NF-1 related $\mathrm{BrCa}$ arises earlier ( $<50$ years) and is more advanced, with an increased mortality. NF-1 is one of the most frequent monogenic diseases worldwide and a tumor predisposition syndrome. The Nf1 gene is an important negative regulator of the Ras oncogene and belongs to the family of the 12 the most important $\mathrm{BrCa}$ predisposition genes. Planning introduction of BrCa screening guidelines for NF-1 women in Poland we started with assessment of $\mathrm{BrCa}$ risk awareness and current preventive practices in this population by a survey published in an open access internet profile dedicated exclusively to patients with NF-1 in Poland, with 1928 participants. As a result, we revealed that the awareness of this specific risk was declared by only $30 \%$ out of 138 responders, and only $21 \%$ of them received this information from medical professionals. In all 4 (2.89\%) women suffering from $\mathrm{BrCa}$ the cancer was diagnosed before the $50^{\text {th }}$ year of age. It exceeds significantly the expected prevalence of $\mathrm{BrCa}$ in the general population of Polish women. We conclude that the limited awareness of NF-1 related $\mathrm{BrCa}$ risk in Polish patients warrants the educational effort directed both to the NF-1 patients by professional counseling and to the medical community, in order to increase the efficacy of preventive measures and decrease $\mathrm{BrCa}$ mortality.

Key words: neurofibromatosis type 1 breast cancer inherited risk, cancer predisposition syndromes.

Contemp Oncol (Pozn) 2020; 24 (2): 140-144 DOI: https://doi.org/10.5114/wo.2020.97637

\section{Breast cancer risk (un)awareness among women suffering from neurofibromatosis type 1 in Poland}

\author{
Marek W. Karwacki
}

Coordinated Medical Care Center for Neurofibromatoses and related RASopathies, Department of Pediatrics, Hematology and Oncology, Medical University of Warsaw, Warsaw, Poland

\section{Introduction}

According to the World Health Organization's Globocan 2018, with an exact number of a new cases of 20 203, the population age-standardized (world) incidence of breast cancer (BrCa) in Poland is 59.1 per 100000 [1]. Despite favorable mortality trends since the 1990s in Europe [2], Poland is the only country where the BrCa mortality rate is currently increasing [3]. In $30 \%$ of women with $\mathrm{BrCa}$ in Poland, the disease progresses to an advanced stage, and in $5-10 \%$ of patients it is diagnosed when it has already metastasized to other organs [1]. This requires conducting appropriate surveillance meaning improved BrCa prevention, diagnosis and management in Poland. The main recognized environmental determinants of $\mathrm{BrCa}$ are reproductive and hormonal factors, and obesity in postmenopausal women [4]. Genetic factors responsible for the inherited risk of $\mathrm{BrCa}$ are of utmost importance for given families carrying common germline mutations in $\mathrm{BrCa}$ predisposition genes. Currently 12 out of many other genes are commonly assumed as the most frequent BrCa predisposition genes: ATM, BARD1, BRCA1, BRCA2, CDH1, CHEK2, Nf1, PALB2, PTEN, RAD51C, RAD51D, and TP53 [5]. Regarding the Nf1 gene, the so-called first hit mutation warranted that further carcinogenesis is inherited germinally in patients with neurofibromatosis type 1 (NF-1) $[6,7]$.

NF-1, with a prevalence of 1 in 2.5-3 thousand live births [6-8] or higher ( $1: 1800-2000$ [9-11]), is one of the most frequent monogenic trait diseases worldwide, regardless of the race and place of living. The morbidity of NF-1 is impressive as well, due to reported reduction in average sex-independent life expectancy of an 8 to 15-year maximum [12,13] or even less [9], and the average life longevity of 50-60 years in industrialized countries [12]. The common worldwide observation reveals that a large proportion of NF-1 patients may not be correctly identified or ignored by health practitioners due to inadequacy of health-care systems [6-8]. With 100\% penetration of the gene mutation it is characterized by unique, age-dependent extreme variability in phenotypic expression, observed not only between affected patients from different families, but within the same family as well. Age-dependent clinical expressivity of phenotypic manifestations make the clinical diagnosis possible at the $7^{\text {th }}-10^{\text {th }}$ year of patients' life only, but it reaches essentially $100 \%$ by adolescence [6-8]. Molecular diagnosis of NF-1 is easily available nowadays but the exact diagnosis is still based mainly on clinical criteria that are highly specific and sensitive for adults with NF-1 (Table 1) [15, 16].

The precise molecular mechanism of NF-1 resulted mostly from pathogenic sequence variants and rarely from microdeletion within the Nf1 gene [17, 18]. This gene encodes neurofibromin, a still enigmatic protein ubiquitously expressed in human cells with varying expressivity depending on the tissue type and developmental stage of the organism [17]. It is a negative regulator 
Table 1. NF-1 NIH Consensus Development Conference Criteria of 1988 (NIH-CC-88) (adapted from [7] and [15])

\begin{tabular}{|c|c|}
\hline Clinical criterion & Comment \\
\hline $\begin{array}{l}\text { Six or more cafe au lait macules (CALMs) equal to or greater } \\
\text { than } 5 \mathrm{~mm} \text { in longest diameter in prepubertal patients } \\
\text { and } 15 \mathrm{~mm} \text { in longest diameter in postpubertal patients }\end{array}$ & $\begin{array}{l}\text { 2-3 or fewer CALMs might be present in healthy population } \\
\text { CALMs are present since infancy and typically have smooth edges }\end{array}$ \\
\hline $\begin{array}{l}\text { Two or more neurofibromas of any type or } 1 \text { plexiform } \\
\text { neurofibroma }\end{array}$ & $\begin{array}{l}\text { Dermal and subcutaneous neurofibromas are } \\
\text { typically detectable since } 6-10 \text { years of age } \\
\text { Plexiform neurofibroma typically disfigures or changes the color } \\
\text { and texture of overlying skin }\end{array}$ \\
\hline $\begin{array}{l}\text { Freckling in the axillary or inguinal regions } \\
\text { (Crowe sign) }\end{array}$ & $\begin{array}{l}\text { Not typically detectable until age of } 5 \text { or later } \\
\text { Freckling in areas not exposed to the sun (e.g. under the breast } \\
\text { in women and in axillary or inguinal regions) is unexpected in people } \\
\text { without NF-1 }\end{array}$ \\
\hline Optic glioma (OPG) & $\begin{array}{l}\text { May be present in infancy and become stable since } 10 \text { years of age } \\
\text { or later on in the majority of patients } \\
\text { Early detection critical for preserving vision }\end{array}$ \\
\hline Two or more iris hamartomas (Lisch nodules) & $\begin{array}{l}\text { Occurrence is age related, but frequently observed from 5-10 years } \\
\text { of age } \\
\text { Hardly detectable visually (without slit-lamp examination) }\end{array}$ \\
\hline $\begin{array}{l}\text { A distinctive osseous lesion, such as sphenoid } \\
\text { wing dysplasia or long-bone dysplasia (with } \\
\text { associated cortical thickening and medullary } \\
\text { canal narrowing), with or without } \\
\text { pseudarthrosis }\end{array}$ & $\begin{array}{l}\text { Tibial dysplasia is the most common type of inherited bone } \\
\text { dysplasia in NF-1 but observed in less than } 2 \% \text { of patient population }\end{array}$ \\
\hline $\begin{array}{l}\text { A first-degree relative (parent, sibling, or child) } \\
\text { with NF-1 according to the aforementioned } \\
\text { criteria }\end{array}$ & $\begin{array}{l}\text { Parent who is affected should have at least diagnostic number } \\
\text { of CALMs (100\% penetrance) } \\
\text { NF-1 does not skip a generation } \\
\text { The disease is characterized by app. } 50 \% \text { frequency of new mutation } \\
\text { affecting the patient but not inherited from parents }\end{array}$ \\
\hline
\end{tabular}

of the Ras oncogene. Deregulated Ras expression results in activation of downstream proteins and transcription factors leading to multiorgan disturbances, uncontrolled cell divisions, disturbed apoptosis and many others [6-8, 18-20]. Germline loss and homozygous inactivation of Nf1 lead to tumor formation in NF-1 patients, whereas biallelic somatic loss of $N f 1$ is commonly found in many different types of cancers worldwide and may indicate that neurofibromin plays a key role in cancer genesis much beyond what is evident in NF-1, a tumor predisposition syndrome [19-21].

The increased risk of BrCa in NF-1 patients (not only women) has been suggested in several cohort and epidemiological studies [22-29]. Somatic mutations of Nf1 seemed to be present in almost 30\% of all breast carcinomas regardless of NF-1 diagnosis and have been implicated as genomic drivers in $\mathrm{BrCa}[30,31]$. The currently published meta-analysis done by Suarez-Kelly suggests that in comparison to the general population the risk of $\mathrm{BrCa}$ in NF-1 women of age less than 50 is a five-fold increase and $\mathrm{BrCa}$ in NF-1 arises earlier and is more advanced with an increased mortality [29].

As many authors postulated introduction of early $\mathrm{BrCa}$ screening guidelines for NF-1 women [22-29], we decided to start with assessment of BrCa risk awareness and current preventive practices among NF-1 women in Poland. According to the cited epidemiological data [3], we may expect that the forthcoming program would improve rethe increased $\mathrm{BrCa}$-related death rate has been growing recently, but significantly in this specific population.

\section{Material and methods}

The Coordinated Medical Care Center for Neurofibromatoses and related RASopathies (CMCC-NF/RAS) is one out of 3 reference centers providing integrated and coordinated [7], multispecialty care for patients suffering from NF-1, NF-2, schwannomatosis and Legius syndrome and their mosaic and allelic forms of NF-1 in Poland. The simple and not time consuming, open access and voluntary, NF-1 population-based survey questionnaire was published on the Facebook CMCC-NF/RAS profile (https://www. facebook.com/Neurofibromatozy-strona-dr-Marka-Karwackiego-2319943098240651/). It is selectively dedicated to NF-1 patients from all over the country with 1928 participants and 542 permanently active at the time of publication. It was advertised and spread over as well by the Web Site of the patients' and parental organization "Alba Julia - Neurofibromatoses-Poland Association" (NGO) (http:// alba-julia.pl/) and its FB profile, the only organization for NF patients in Poland. The society assembles more than 1200 NF/RAS patients actually but influences many more. As there is no NF-1 registry in Poland both contacts are the only widely used sources of knowledge and information for NF/RAS patients and their families, concerning medical care official organization and disease course. The ques- sults of BrCa treatment and mortality in a country where 
tionnaire consisted of $15^{\text {th }}$ closed questions with limited choices was made up utilizing free software offered by "Google Forms: Free Online Surveys for Personal Use" as the resource. The study received approval from the Medical University of Warsaw Ethical Committee.

\section{Results and discussion}

The demography and medical characteristics of the responding group of 138 women are presented in Table 2 and Figure 1 . Among the responders, whose median age was 34 years, 5 were younger than 16, the official age when a patient has a right to decide by herself in Poland; the youngest one was 13 (Table 2A). In our center the information concerning BrCa risk in NF-1 is usually provided to the patient together with genetic counselling from 16 years of age, if not requested earlier. Anyway, the information is not limited to adults only and all children present in the office during the NF-1 visit may receive the answer to every question they have, modified by the age-specific perception of the patient. As emphasized by the author and ethical committee in the survey preamble, everyone who may feel uncomfortable with information concerning so far undisclosed risk of $\mathrm{BrCa}$ always had a chance to receive a precise explanation and counselling. In relation to this (Table 2B.3), the majority of women (67.9\%) who finally received subjective information understand properly that the risk of $\mathrm{BrCa}$ in NF-1 exceeds the populational risk, but is still not high [27, 29]. In contrast, 5 out of 28 counselled (17.8\%) received the information or presumed this risk as high. Unfortunately, $14.3 \%$ have been left with this information without an explanation how influential the risk is.

Excluding the medical specialties not usually engaged in NF-1 diagnosis and care (all together 33\%), according to the survey's responses most frequently NF-1 patients have been diagnosed by so called an NF specialist in NF/ RAS centers (18\%; Table 2B.1), which may reflect the rising awareness concerning NF/RAS comprehensive care in

Table 2. Characteristics and demography of the responders $(n=138)$ of our NF-1 population survey

\begin{tabular}{|c|c|c|c|c|}
\hline Characteristic & Mean & Median & SD & Range \\
\hline \multicolumn{5}{|l|}{ A. Demography of the group } \\
\hline Age of the responders & 33.17 & 34.00 & 9.627 & $13-63$ \\
\hline Age at diagnosis & 16.34 & 12.00 & 12.895 & $0-62$ \\
\hline $\begin{array}{l}\text { Age at diagnosis among } 83 \text { women whose diagnosis } \\
\text { according to } \mathrm{NIH}-\mathrm{CC}-88 \text { criteria ought to be obvious } \\
\text { from } 10 \text { years of age* }\end{array}$ & 24.48 & 25.00 & 10.318 & $11-62$ \\
\hline \multicolumn{5}{|l|}{ B. Clinical characteristics of the group } \\
\hline \multirow[t]{2}{*}{ B.1. NF-1 status } & \multicolumn{2}{|c|}{ NF-1 status } & \multicolumn{2}{|c|}{ Natality status } \\
\hline & $\begin{array}{c}\text { Sporadic: } \\
84 / 138(71.8 \%)\end{array}$ & $\begin{array}{l}\text { Familial: } \\
\text { 54/138 (39.2\%) }\end{array}$ & $\begin{array}{l}\text { Parturient: } \\
56 / 138(40.6 \%)\end{array}$ & $\begin{array}{l}\text { Childless: } \\
82 / 138(59.4 \%)\end{array}$ \\
\hline \multirow[t]{2}{*}{ By whom the primary diagnosis of NF-1 was made } & $\begin{array}{l}\text { NF specialists } \\
24 / 138(18 \%)\end{array}$ & $\begin{array}{l}\text { Neurologists } \\
18 / 138(13 \%)\end{array}$ & $\begin{array}{l}\text { Family doctor } \\
11 / 138(8 \%)\end{array}$ & $\begin{array}{l}\text { Geneticist } \\
14 / 138(10 \%)\end{array}$ \\
\hline & $\begin{array}{l}\text { Patient by herself } \\
11 / 138(8 \%)\end{array}$ & $\begin{array}{l}\text { Oncologist } \\
10 / 138(7 \%)\end{array}$ & $\begin{array}{l}\text { Ophthalmologist } \\
4 / 138(3 \%)\end{array}$ & $\begin{array}{l}\text { Other med. } \\
\text { specialists } \\
46 / 138(33 \%)\end{array}$ \\
\hline $\begin{array}{l}\text { B.2. Primary screening of breast tumors declared } \\
\text { by responders prior to NF-1 related BrCa risk } \\
\text { counseling }\end{array}$ & $\begin{array}{l}\text { Self-examination } \\
49 / 138(35.5 \%)\end{array}$ & $\begin{array}{l}\text { Breast } \\
\text { ultrasound } \\
67 / 138(48.6 \%)\end{array}$ & $\begin{array}{l}\text { Mammography } \\
16 / 138(11.6 \%)\end{array}$ & $\begin{array}{l}\text { No screening } \\
\text { at all } \\
6 / 138(4.3 \%)\end{array}$ \\
\hline \multicolumn{5}{|l|}{$\begin{array}{l}\text { B.3. Professional counselling regarding } \mathrm{BrCa} \\
\text { prophylactic examinations and its perception } \\
\text { among NF-1 women in our population survey }\end{array}$} \\
\hline Patients received the information: $29 / 138$ (21.0\%) & \multicolumn{2}{|c|}{ Refused to answer: 1} & \multicolumn{2}{|c|}{ Reported the data: 28} \\
\hline $\begin{array}{l}\text { Post-counseling perception of BrCa risk between the } \\
\text { NF-1 women based on information received from } \\
\text { a doctor (counselor) }\end{array}$ & $\begin{array}{l}\text { Finally, not } \\
\text { conveyed by } \\
\text { a doctor } \\
4 / 28(14.3 \%)\end{array}$ & $\begin{array}{l}\text { Meaningless } \\
0 / 28(0 \%)\end{array}$ & $\begin{array}{c}\text { Exceeding the } \\
\text { populational risk, } \\
\text { but not high } \\
19 / 28(67.9 \%)\end{array}$ & $\begin{array}{l}\text { High } \\
5 / 28(17.8 \%)\end{array}$ \\
\hline $\begin{array}{l}\text { Recommended method of BrCa prophylaxis } \\
\text { acknowledge by NF-1 women after counseling }\end{array}$ & $\begin{array}{l}\text { Self-examination } \\
1 / 28(3.6 \%)^{\star *}\end{array}$ & $\begin{array}{c}\text { Regular } \\
\text { ultrasound } \\
\text { screening } \\
16 / 28(57.1 \%)\end{array}$ & $\begin{array}{l}\text { Regular } \\
\text { mammography } \\
4 / 28(14.3 \%)\end{array}$ & $\begin{array}{l}\text { Regular breast } \\
\qquad \text { MRI } \\
7 / 28(25.0 \%)\end{array}$ \\
\hline $\begin{array}{l}\text { Patient's final declaration of compliance with } \\
\text { recommended method of BrCa prophylaxis }\end{array}$ & \multicolumn{4}{|c|}{25 out of 28 interviewed women (89.3\%) } \\
\hline \multicolumn{5}{|l|}{ C. BrCa incidence: $4 / 138$ (2.89\%) } \\
\hline Age at diagnosis of $\mathrm{BrCa}$ & $\begin{array}{l}<30 \text { years of age } \\
0\end{array}$ & $\begin{array}{l}3^{\text {rd }} \text { decade of life } \\
1(0.7 \%)\end{array}$ & $\begin{array}{c}4^{\text {th }} \text { decade of life } \\
3(2.2 \%)\end{array}$ & $\begin{array}{c}>50 \text { years of age } \\
0\end{array}$ \\
\hline
\end{tabular}

NF-1 - neurofibromatosis type 1, BrCa-breast cancer, " see text, "* advised by an oncologist 


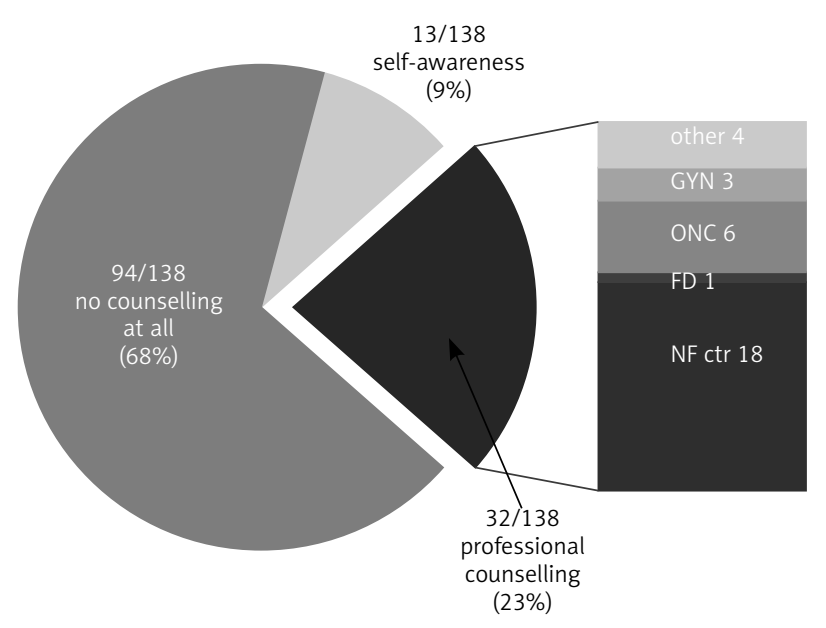

"self-awareness" - patients who get knowledge by themselves from media (press or internet), professional counselling - patients who received counselling during NF visit from: NF medical coordinator of NF/RAS reference center (NF ctr), family doctor (FD), oncologist (ONC), gynecologist (GYN), other MD professionals

Fig. 1. Sources of and general awareness of breast cancer risk among women suffering from NF-1 in our population survey

Poland. The increasing role of NF/RAS Reference Centers, active since 2005 and currently supported by Ministry of Health regulations, ensures the proper early diagnoses and eligibility of NF-1 women for the NF-1 related $\mathrm{BrCa}$ prophylactic program [7]. Probably that is why the mean age at diagnosis of NF-1 in the surveyed women as a whole was 16.34 years with a median of 12 (Table 2A). It is promising for the projected program of BrCa prophylaxis in NF-1 women in Poland. Unfortunately in contrast, the oldest patient newly diagnosed as having NF-1 was a 62-yearold woman and the median age of diagnosis in a group of 83 women older than 10 at admission to the professional diagnosis centers (when the diagnosis of NF-1 according to $\mathrm{NIH}-\mathrm{CC}-88$ clinical criteria only is easy and unquestionable) was 25 . It raises the question of medical care quality in Poland and the possibility to introduce a program of early detection of BrCa in the NF-1 population with success, when a number of them might not be diagnosed properly in the right time.

The important message revealed throughout the survey is significantly limited knowledge about the NF-1-related risk of $\mathrm{BrCa}$ (Fig. 1). Thus, $68 \%$ of surveyed women did not receive such information at all, whereas only $23 \%$ had professional counselling and mostly received in NF centers. There were women as well who found this information in media by themselves (9\%) without any support from the professional medical services. Fortunately (Table 2B.2), according to their statements almost half of the group (48.6\%) had ultrasound and $11.6 \%$ had mammography screening done before the professional counselling concerning NF-1 related risk of $\mathrm{BrCa}$ and $35.5 \%$ declared self-examination of the breast, whereas only $4.3 \%$ disregard screening completely. Breast ultrasound is preferred and the chip method of BrCa screening in NF-1 women but with one limitation - sometimes it is hard to disclose probable BrCa among the multiple neurofibromas affecting both glands. The method of advanced imaging in this situation, preferred for women with NF-1, is still a matter of debate, and European and US standards are conflicting. In the US the chosen method of advanced screening and more precise diagnosis than provided by ultrasound is magnetic resonance imaging [32]. Mammography is assumed as dangerous in NF-1, as irradiation may provoke the malignant transformation of breast plexiform neurofibroma(s) into malignant peripheral nerve sheath tumor [19-21]. In this context, according to the survey results (Table 2B.3), the most frequently advised method of BrCa screening in Poland was breast ultrasound (51.7\%) done on a regular yearly basis and MR imaging (25.0\%) as a more advanced examination made regularly (not reimbursed by the Polish NHS). Regular mammography has been advised to $14.3 \%$ of NF-1 women, which probably reflects the limitations of the Polish health system. The only advice of recommended breast self-examination was given by an oncologist, which is puzzling in regard to the known early risk of $\mathrm{BrCa}$ in NF-1 women. What is more important, almost $90 \%$ of counselled women declared compliance with the advertised method of BrCa prophylaxis.

There are two final interesting findings, which may reflect the suitability of the early prophylaxis of BrCa in NF-1 women in Poland. The most important is that $\mathrm{BrCa}$ has been diagnosed in 4 out of 138 (2.89\%; Table 2C) women and before 50 years of age (the most important message). However naive and simplified, estimation of the expected number of affected women in the surveyed cohort according to BrCa populational incidence in Poland [1] seems to be 0.08 per 138 patients (expected $0.006 \%$ vs. actual $2.89 \%)$. Thus, the result of the survey is revealing in this respect.

The other important observation is based on the discrepancy between the surveyed cohort demography and the remaining population of NF-1 patients. As shown in Table $1 \mathrm{~A}$, in our cohort women with sporadic or spontaneous mutation (71.8\% vs. expected app. 50\% in general NF-1 population) and nulliparous (or childless $-59.4 \%$, whereas the median age of the group was 34.0 years) dominated the group. This overrepresentation, especially concerning women with spontaneous mutation, may reflect the higher level of fear among NF-1 women who had no experience with the disease which had not burdened their family members in the past. Although it is a pure speculation of the author, probably women growing up in a family where many members were affected and most of them did not present a severe NF-1 phenotype (described in the introduction), might not be scared as much as patients who had not experienced the disease before. It may yet be further confirmed by the relatively high number of NF-1 women undergoing prophylactic breast ultrasound even before the professional counselling. The high proportion of nulliparous women is the finding which may raise a question concerning the fear of NF-1 women against pregnancy and their preferences in regard to high risk of disease transmission. Both observations must be taken into account when a BrCa prophylaxis program is to be established.

Even if the presented cohort is not representative in regard to statistical analyses and limited because of voluntary access and response bias, the represented opinions 
are very important and provide not only a background for future guidelines preparation, but reveal the ignorance of patients and doctors in Poland concerning the risk and preventive measures of $\mathrm{NF}-1$ related $\mathrm{BrCa}$.

\section{Conclusions}

The well-documented risk of BrCa in women suffering from NF-1, confirmed in our study as well, requires implementation of a national program of appropriate surveillance and early detection of $\mathrm{BrCa}$ in this given population.

The limited awareness of NF-1 related BrCa risk in Polish patients warrants educational efforts directed both to the NF-1 patients by professional counseling and to the medical community, in order to increase the efficacy of preventive measures and decrease BrCa mortality.

\section{The author declares no conflict of interest.}

\section{References}

1. Ferlay J, Colombet M, Soerjomataram I, Mathers C, Parkin DM, Piñeros M, Znaor A, Bray F. Estimating the global cancer incidence and mortality in 2018: GLOBOCAN sources and methods. Int I Cancer 2019; 144: 1941-1953.

2. Carioli G, Malvezzi M, Rodriguez T, Bertuccio P, Negri E, La Vecchia C. Trends and predictions to 2020 in breast cancer mortality in Europe. Breast 2017; 36: 89-95.

3. Malvezzi M, Carioli G, Bertuccio P, Boffetta P, Levi F, La Vecchia C, Negri E. European cancer mortality predictions for the year 2019 with focus on breast cancer. Ann Oncol 2019; 30: 781-787.

4. Rosato V, Bosetti C, Negri E, et al. Reproductive and hormonal factors, family history, and breast cancer according to the hormonal receptor status. Eur J Cancer Prev 2014; 23: 412-417.

5. Couch FJ, Hu C, Hart CN, et al. Population-based breast cancer risk estimates for predisposition gene mutations: Results from the CARRIERS study. Poster presentation at 2019 San Antonio Breast Cancer Symposium; December 10-14, 2019; San Antonio, TX. Abstract PD3-01.

6. Miller DT, Freedenberg D, Schorry E, Ullrich NJ, Viskochil D, Korf BR. Council of Genetics; American College of Medical Genetics and Genomics. Health Supervision for Children with Neurofibromatosis Type 1. Pediatrics 2019; 143: pii: e20190660

7. Karwacki M, Wysocki M, Perek-Polnik M, Jatczak-Gaca A. Coordi nated medical care for children with neurofibromatosis type 1 and related RASopathies in Poland. Arch Med Sci 2019. doi:10.5114/ aoms.2019.85143.

8. Stewart DR, Korf BR, Nathanson KL, Stevenson DA, Yohay K. Care of adults with neurofibromatosis type 1: a clinical practice resource of the American College of Medical Genetics and Genomics (ACMG). Genet Med 2018; 20: 671-682.

9. Kallionpää RA, Uusitalo E, Leppävirta J, Pöyhönen M, Peltonen S, Peltonen J. Prevalence of neurofibromatosis type 1 in the Finnish population. Genet Med 2018; 20: 1082-1086.

10. Stark AE. Variation in Prevalence of Rare Heritable Traits - A Simulation Study - Illustrated by Neurofibromatosis Type 1. Twin Res Hum Genet 2019; 22: 229-232.

11. Pemov A. Estimation of Frequency of Pathogenic Variation in NF1, SPRED1 and MAPK1/3 in Unaffected Populations using Public Genomic Databases. 2018 Joint Global Neurofibromatosis Conference, Paris, France, November 2-6, 2018. Book of abstracts: 117.

12. Evans DG, O'Hara C, Wilding A, et al. Mortality in neurofibromatosis 1: in North West England: an assessment of actuarial survival in a region of the UK since 1989. Eur J Hum Genet 2011; 19: 1187-1191.

13. Uusitalo E, Leppävirta J, Koffert A, et al. Incidence and mortality of neurofibromatosis: a total population study in Finland. J Invest Dermatol 2015; 135: 904-906.
14. Wilding A, Ingham SL, Lalloo F, Clancy T, Huson SM, Moran A, Evans DG. Life expectancy in hereditary cancer predisposing diseases: an observational study. J Med Genet 2012; 49: 264-269.

15. Neurofibromatosis. Conference statement. National Institutes of Health Consensus Development Conference. Arch Neurol 1988; 45: 575-578.

16. DeBella K, Szudek J, Friedman JM. Use of the national institutes of health criteria for diagnosis of neurofibromatosis 1 in children. Pediatrics 2000; 105: 608-614.

17. Peltonen S, Kallionpää RA, Peltonen J. Neurofibromatosis type 1 (NF1) gene: Beyond café au lait spots and dermal neurofibromas. Exp Dermatol 2017; 26: 645-648.

18. Fadhlullah SFB, Halim NBA, Yeo JYT, et al. Pathogenic mutations in neurofibromin identifies a leucine-rich domain regulating glioma cell invasiveness. Oncogene 2019; 38: 5367-5380.

19. Kiuru M, Busam KJ. The NF1 gene in tumor syndromes and melanoma. Lab Invest 2017; 97: 146-157.

20. Evans DG. What Is the Malignancy Risk in Neurofibromatosis Type 1? J Clin Oncol 2016; 34: 1967-1969.

21. Uusitalo E, Rantanen M, Kallionpää RA, et al. Distinctive Cancer Associations in Patients with Neurofibromatosis Type 1. J Clin Oncol 2016; 34: 1978-1986.

22. Brasfield RD, Das Gupta TK. Von Recklinghausen's disease: a clini copathological study. Ann Surg 1972; 175: 86-104.

23. Zoller MET, Rembeck B, Oden A, Samuelson M, Angervall L. Malig nant and benign tumors in patients with neurofibromatosis type 1 in a defined Swedish population. Cancer 1997; 79: 2125-2131.

24. Sharif S, Moran A, Huson SM, Iddenden R, Shenton A, Howard E, Evans DGR. Women with neurofibromatosis 1 are at a moderately increased risk of developing breast cancer and should be considered for early screening. J Med Genet 2007; 44: 481-484.

25. Madanikia SA, Bergner A, Ye X, Blakeley JO. Increased risk of breast cancer in women with NF1. Am J Med Genet A 2012; 158A: 3056 3060.

26. Wang X, Levin AM, Smolinski SE, Vigneau FD, Levin NK, Tainsky MA. Breast cancer and other neoplasms in women with neurofibromatosis type 1: a retrospective review of cases in the Detroit metropolitan area. Am J Med Genet A 2012; 158A: 3061-3064.

27. Seminog OO, Goldacre MJ. Age-specific risk of breast cancer in women with neurofibromatosis type 1. Br J Cancer 2015; 112: 1546 1548

28. Uusitalo E, Kallionpää RA, Kurki S, et al. Breast cancer in neurofibromatosis type 1: overrepresentation of unfavourable prognostic factors. Br J Cancer 2017; 116: 211-217.

29. Suarez-Kelly LP, Yu L, Kline D, Schneider EB, Agnese DM, Carson WE. Increased breast cancer risk in women with neurofibromatosis type 1: a meta-analysis and systematic review of the literature. Hered Cancer Clin Pract 2019; 17: 12.

30. Wallace MD, Pfefferle AD, Shen L, et al. Comparative oncogenomics implicates the neurofibromin 1 gene (NF1) as a breast cancer driver. Genetics 2012; 92: 385-396.

31. Cancer Genome Atlas Network. Comprehensive molecular portraits of human breast tumors. Nature 2012; 490: 61-70.

32. Pradhan D, Kaur N, Gami A, Hura KS, Garg G, Mohanty SK. Neurofibromatosis and breast cancer: Do we need to revise the mammographic screening schedule in patients of neurofibromatosis? I Cancer Res Ther 2017; 13: 583-585.

\section{Address for correspondence}

\section{Marek W. Karwacki}

Coordinated Medical Care Center for Neurofibromatoses and related RASopathies Department of Pediatrics, Hematology and Oncology

Medical University of Warsaw

63A Żwirki i Wigury St.

02-091 Warsaw, Poland

e-mail: mwkarwacki@gmail.com

Submitted: 13.05 .2020

Accepted: 24.06 .2020 